\title{
Interaction between business and government as a threat to the economic security of the state
}

\author{
Marina Vlasova ${ }^{1, *}$, Olga Stepchenkova $^{2}$, Irina Lobanova ${ }^{2}$, and Anastasiia Smirnova $^{3}$ \\ ${ }^{1}$ Saint-Petersburg State University of Economics, 21, Sadovaya st., St.-Petersburg, Russia \\ ${ }^{2}$ Saint-Petersburg International Banking Institute, 60, Nevsky Av., St.-Petersburg, Russia \\ ${ }^{3}$ Norilsk State Industrial Institute, 7, 50 let Oktyabrya st., Norilsk, Russia
}

\begin{abstract}
The article considers the costs of interaction between the state and business as a threat to the development of the economy of the Russian Federation from the point of view of economic security ensuring. The authors identified significant obstacles both from the business side and from the state apparatus, which pose a threat to economic security. The study is of interest for the further development of the system for the economic security ensuring of the Russian Federation.
\end{abstract}

\section{Introduction}

Economic security is a modern and dynamically developing direction of economic thought in the Russian Federation (RF). The task of economic security is to ensure the sustainable development of the economy by determining the state of the economic system through the system of indicators and its threshold values, monitoring and forecasting of internal and external threats, the development of the necessary mechanisms and activities. V.K. Senchagov is one of the founders of the national concept of economic security. He defined the positive state as "a state of the economy and institutions of power, which ensures guaranteed protection of national interests, socially directed development of the country as a whole, sufficient defense potential" [1]. The relevance of the study lies in the need to find the ways to counter the main threats to Russia's economic security. It can be resource dependence, technological backwardness, reducing the quality of life of the population, economic sanctions, accession to the WTO, etc.

The Strategy for Economic Security of the RF until 2030 defines the support for hightech small and medium-sized businesses (SMEs) as one of the main tasks of realizing sustainable growth in the real sector of the economy [2,3]. The problems of interaction between business and government force the business community to seek the ways to defend their interests within the legal framework. It often doesn't give positive results because of the fundamental differences in the work of state and private structures. On the other hand, the question is raised up from the low effectiveness of state support for SMEs, although it is the alleged leader of the innovative economy development in the RF. State economic policy to support SMEs is a series of subsidies and benefits, the purpose of which is to increase the

\footnotetext{
*Corresponding author: vms68@yandex.ru
} 
number of enterprises, the number of jobs, revenues to the budget, etc. There are contradictions and confrontations in the sphere of interaction between business and authorities, despite the counter-movement towards each other. That gives the prerequisites for costs on both sides. In economic theory they are called transactional. The identification of these costs is of particular interest as a subject of research within the framework of economic security, since these costs may pose a threat to the stability and development of the economy of the Russian Federation.

\section{Research methodology and statistics}

The research uses the principle of systematic research work, the connection between theory and practice. The scientific and theoretical basis of this project is number of publications and studies of domestic and foreign scientists. The research uses data from official statistical observation and expert studies. Small and medium-sized enterprises are an important part of the socio-economic system in the context of dynamically developing market relations in Russia. The share of small businesses in developed countries is more than $50 \%$ of the total number of enterprises, in Russia this figure is at the level of $20 \%$. Innovative SMEs are an important source of growth for a large innovative business. Hightech companies such as Google, Apple and CISCO build up their potential by absorbing small innovative companies and acquiring patents for their inventions and developments. The innovative activity in the leading European countries (Germany, France, Finland) is rapidly striving for $100 \%$. The innovative activity of enterprises in Russia is still at a rather low level - about $9 \%$ of the total number of companies. By 2020, the Government plans to increase the volume of the innovative component in the following indicators: the number of enterprises - up to $40-50 \%$, the share in the gross domestic product - up to $20 \%$, part of innovative products - up to 25-35\% [4]. Small business in Russia faces a number of difficulties. Among the main problems: increasing tax burden, high cost of loans, corruption, declining purchasing power of the population. These problems give rise to skepticism about private business among Russian citizens: the majority of the population (about 90\%) does not even consider self-employment as an alternative to wage labor in private or public spheres. While approximately 38 million people of working age do not work anywhere [5]. Potential and current entrepreneurs indicate unfriendly business conditions associated with low investment efficiency, due to high interest rates, low activity of the goods and services market, lack of necessary infrastructure elements, frequent changes in legislation, etc. (Fig. 1). Thus, already at the start, they give up and only 5\% of SMEs come to the finish line; those who managed to adapt and find their unique business niche [6].
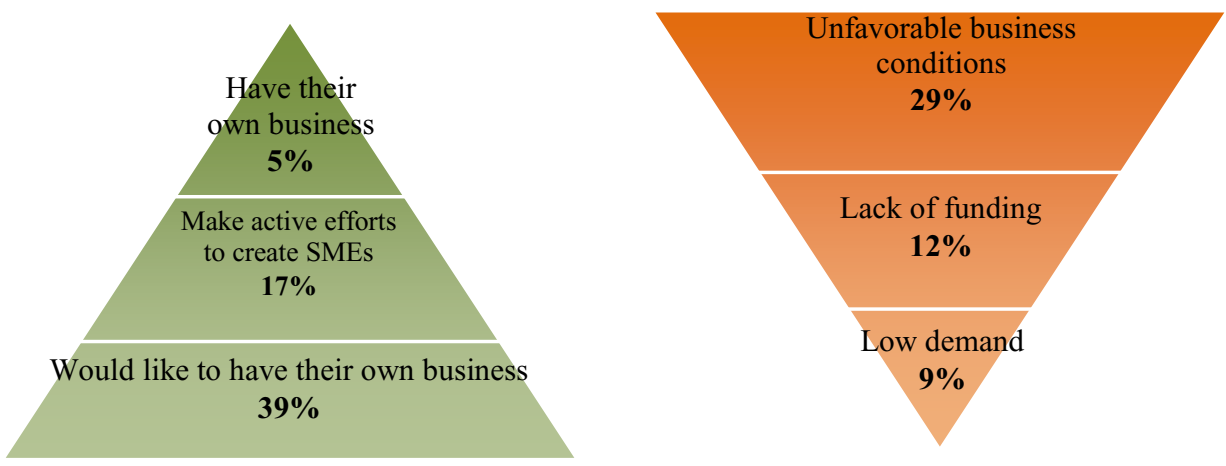

Fig. 1. The main contradictions in the SMEs development (compiled by the authors). 


\section{Interaction of small business with authorities}

There have been significant changes in the sphere of interaction between business and government since private business in Russia appeared twenty-seven years ago. Support for entrepreneurship today is one of the first places in the state economic policy. The authorities create new institutions of interaction to improve the effectiveness of support. The creation of an open economy is on the agenda. The work of the authorities is based on the principles of openness, efficiency, public control, the involvement of business and society in decision-making processes, and increasing investment attractiveness. Thanks to this work the amount of SMEs increased in 2016 up to 2816 thousand units compared to 2015 (2080 thousand units). It is connected with the beginning of the work of the Single Register of Legal Entities of the Federal Tax Service.

Table 1. Dynamics of the number of SMEs according to the Federal Service of State Statistics and the Federal Tax Service (in thousands) (Source: compiled by the authors).

\begin{tabular}{|c|c|c|c|}
\hline Period & $\begin{array}{c}\text { Number } \\
\text { of SMEs }\end{array}$ & $\begin{array}{c}\text { Number of } \\
\text { bankruptcies }\end{array}$ & $\begin{array}{c}\text { \% of } \\
\text { bankruptcies }\end{array}$ \\
\hline 2007 & 1137 & 5,6 & 0,49 \\
\hline 2008 & 1362 & 6,4 & 0,47 \\
\hline 2009 & 1595 & 11,6 & 0,73 \\
\hline 2010 & 1669 & 12,5 & 0,75 \\
\hline 2011 & 2013 & 10,3 & 0,51 \\
\hline 2012 & 2003 & 9,7 & 0,48 \\
\hline 2013 & 2063 & 10,6 & 0,51 \\
\hline 2014 & 2103 & 12,5 & 0,59 \\
\hline 2015 & 2080 & 12,6 & 0,61 \\
\hline 2016 & 2816 & 12,2 & 0,43 \\
\hline
\end{tabular}

The state is improving existing programs of small and medium-sized businesses support, the number of organizations supporting infrastructure is increasing, funding is growing. The structure of the recipients of state financial support in 2015 was distributed by sector of economics as follows: trade -22 ; services $-26 \%$; construction $-7 \%$; industry - 28\%; transport and communications - 5\%; agriculture - $12 \%$. The number of infrastructure of support organizations has increased in 3 times during the period from 2009 to 2014 and continues to grow (table.2).

Table 2. General indicators of growth in support for SMEs (Source: compiled by the authors).

\begin{tabular}{|l|c|c|}
\hline General indicators & 2009 & 2014 \\
\hline Number of organizations that received support, pcs., incl.: & 214 & 634 \\
\hline Financial support & 120 & 281 \\
\hline Consultations & 24 & 89 \\
\hline Infrastructure & 67 & 230 \\
\hline Export & 3 & 34 \\
\hline Total number of employees, people. & 3872 & 6266 \\
\hline
\end{tabular}

However, in the opinion of entrepreneurs, the existing measures of state support do not work efficiently and, as a rule, are difficult to access. To overcome the existing contradictions and ensure dynamic development, a systematic approach and dialogue between SMEs and state structures is needed. In addition, it is necessary to improve the mechanisms of interaction between large, medium and small businesses. SMEs support infrastructure is actively developing in Saint-Petersburg. In 2010, the Committee for the Entrepreneurship Development and the Consumer Market of the Government of St. 
Petersburg established the Center for the Entrepreneurship Development and Support in St. Petersburg. The Center is a multidisciplinary organization that provides a wide range of services for entrepreneurs on the principle of "one-stop-shop". It provides consulting, conducts training seminars, and protection to SMEs in priority areas of the region's development (for example, in the consumer goods industry). Thus, the infrastructure of state support for SMEs, existing in the region today, is not cooperation, but rather a patronage with a hierarchical structure. At its head there is the interested person - the Government of St. Petersburg. The population takes a passive position. As a summary of the state of the infrastructure for the development of SMEs in Spb a number of incentive and deterrent factors can be identified (Table 3). The effectiveness of any propaganda is made up of two factors: the quality of the propaganda itself and the demand for the product that it propagates. Thus, measures of state support and the promotion of entrepreneurship should be aimed at solving the main problems of entrepreneurship (Tab.4).

Table 3. Factors characterizing the state of small business (Source: compiled by the authors).

\begin{tabular}{|l|l|}
\hline \multicolumn{1}{|c|}{ Stimulating factors } & \multicolumn{1}{c|}{ Constraints } \\
\hline Special tax treatment & Uncertain economic situation \\
\hline Tax holidays & Ruble's exchange rate \\
\hline Simplified reporting system & High level of taxation \\
\hline $\begin{array}{l}\text { Simplification of registration procedures (one } \\
\text { window) }\end{array}$ & Decreasing demand in the domestic market \\
\hline $\begin{array}{l}\text { Creation of business incubators and investment } \\
\text { infrastructure }\end{array}$ & $\begin{array}{l}\text { The quality of legislative regulation of the } \\
\text { economy }\end{array}$ \\
\hline Microfinance & The complexity of bureaucratic procedures \\
\hline Participation of small business in state order & High energy prices \\
\hline Subsidizing & High percentage of commercial loans \\
\hline Information support & High labor costs \\
\hline Surety (state guarantee) & Lack of long-term investment funds \\
\hline
\end{tabular}

The hierarchical structure of state support with a dependence on the center and the absence of feedbacks is a characteristic of an economy of an industrial type. Modern systems of interaction between the state and business abroad are realized on the principle of horizontal interaction as a characteristic feature of the post-industrial economy. In particular, the countries of the Baltic macroregion relied on the organization of economic ties based on the principle of regional innovation ecosystems, on the basis of which the National Innovation Systems (NIS) were established [3,5]. The issue of entrepreneurship propaganda is not sufficiently developed. The population needs direct contact with the government to establish a trusting relationship. The authorities should establish and constantly be in a constructive dialogue with the business. People should receive reasonable motivation to go to small and medium business, engage in entrepreneurship, and benefit the city and the country.

Table 4. Major factors impeding the development of SMEs (compiled by the authors).

\begin{tabular}{|l|l|}
\hline \multicolumn{1}{|c|}{ Subjective } & \multicolumn{1}{c|}{ Objective } \\
\hline $\begin{array}{l}\text { Lack of necessary knowledge for doing } \\
\text { business }\end{array}$ & Lack of effective government action \\
\hline $\begin{array}{l}\text { Low motivation to obtain new } \\
\text { knowledge (business education) }\end{array}$ & Bureaucracy, corruption \\
\hline Unwillingness to legal business & $\begin{array}{l}\text { Absence of transparent conditions for financial } \\
\text { support }\end{array}$ \\
\hline $\begin{array}{l}\text { Non-initiative in the field of upholding } \\
\text { the rights and interests of SMEs }\end{array}$ & Support of large business at the expense of SMEs \\
\hline
\end{tabular}


State and municipal government bodies in the Russian Federation number about 400 thousand people, of which, according to Rosstat (Russian Federal State Statistics Service), only $10 \%$ have an education in the specialty "State and municipal management". The situation with education in the field of entrepreneurship (with the exception of lawyers and accountants) is not better. Any person can become an entrepreneur or a director of a company, and he takes upon himself the risks of interaction with the state, regardless of the size of the company. Thus, the development of the economy should be provided by two methods, which are diametrically opposite in terms of work, and can hardly find mutual understanding and common ground. Inefficiency of interaction is an obstacle in ensuring the economic security of the state and is expressed in the form of uselessly spent budgetary funds, unrealized and unnecessary projects, and constant changes in legislation. According to the data of the World Bank, the state and business in the Russian Federation are losing up to $1.8 \%$ of GDP for exercising control and supervisory functions. The existing pressure from the state authorities forces more than 50\% of SMEs to work in the "shadow economy" [4]. Despite the above-mentioned problems, the population of St. Petersburg and Russia as a whole has a significant staff potential for creating innovative entrepreneurship:

- there are 350 students per 10 thousand population;

- $54 \%$ of citizens aged $25-64$ have higher education $[5,7]$.

\section{Results}

Small business in Russia is mainly represented by the sphere of trade $(40 \%)$. The innovative activity of enterprises is at a low level (9\%). The participation of SMEs in the economy is estimated at $20 \%$ of GDP. Due to unfavorable business conditions, only $5 \%$ of start-ups manage to keep their business afloat. The interaction between business and government is carried out on a hierarchical basis. Private costs of enterprises for the services of the GR-manager, are 30 - 150 (and higher) thousand rubles monthly, depending on the experience and functional of the specialist. The costs of interaction between business and government are estimated at $1.8 \%$ of GDP in general across the country.

\section{Conclusions}

The development of SMEs in the Russian Federation is a fundamental problem.

The state authorities efforts to involve the population in the development of their own business are currently ineffective. The expectations of the population to ensure economic well-being are not related to their own initiative and are mainly shifted to the state's activities to create jobs and improve living standards. The current situation represents a clear threat to the development of the economy and should be thoroughly studied by specialists in economic security.

\section{Discussions}

According to the authors, the fact of transaction costs of interaction between the state and business, which are of scientific interest as an object of research in economic security, is confirmed. They give the data that characterize the existence of low assessment of the work of state structures by entrepreneurs, low activity of the population in organizing their own business, of significant number of applicants for the position of GR-manager, in the absence of appropriate legislative support. 


\section{References}

1. V.K. Senchagov, Russian Federation today, 6 (2007) http://uldelo.ru/2016/04/19/biznesom-vrossii-khochet-zanimatsya-lish-kazhdyi-50-i

2. Decree of the President of the Russian Federation of May 13, 2017 No. 208 (2017) http://www.garant.ru/news/1110785/\#ixzz57dTTCzFs

3. V.V. Okrepilov, S.N. Kuzmina, V.L. Makarov, A.R. Bakhtizin, Economy of Region, 2 (2015)

4. D. Prokofiev, Why no one wants to do business (Business Petersburg, 2013) https://www.dp.ru/a/2013/04/30/Nekreativnie

5. N.V. Smorodinskaya, Journal of Innovation 7, 189 (2014)

6. The World Bank and the European Bank for Reconstruction and Development, Analytical Report on Assessing the Entrepreneurial Climate BEEPS (2012) http://www.ebrd.com/beeps

7. VCIOM (All-Russian Center for the Study of Public Opinion) Analytical report "Russian Small Business in Figures" (2016) http://ibusiness.ru/blog/money/41934 